\title{
Financing the Apple Industry of Jammu and Kashmir: A Review of Literature
}

\author{
Imran Ul Amin ${ }^{1}$, Dr. Anisa Jan ${ }^{2}$ \\ ${ }^{1}$ Research Scholar, School of Business Studies, Islamic University of Science and Technology, \\ Awantipora, $J \& K$. \\ ${ }^{2}$ Assistant Professor, School Of Business Studies, Islamic University of Science and Technology, \\ Awantipora, $J \& K$.
}

\begin{abstract}
Apple is one of the most important horticultural produce and renowned worldwide for its health benefits. Jатти and Kashmir is one of the major apple producing zones in the north India and major portion of population is economically dependent on this industry. The present study shall explore the literature about the apple industry and comparatively try to study the various sources of financing which are presently operational in this very industry. Further using the literature as platform, this study shall also try to draw the conclusions about the efficacy of the various financial intermediaries currently operational in financing the fruit industry of the said region.
\end{abstract}

Keywords: Apple, Finance, industry.

\section{Introduction}

Apple is one of the most important horticultural produce and is renowned worldwide for its taste and health benefits. The Food and Agriculture Organization of the United Nations data show that world production of apple rose by $43.9 \%$ between 1983-85 and 1998-2000, and by 20.3\% further between 1998-2000 and 200810 .Current trends in acreage and yields suggest that world apple production could increase by over $24 \%$ between 2010 and 2020 (BCAI, 2012).

India has emerged as one of the major producer of fruits and vegetables in the world. Contribution of Horticulture sector to the GDP is increasing every year as it contributes about 22 per cent to the gross domestic product and employs about 65 per cent of the rural workforce (Choudhary S.K. (2013)).With the focused attention given to horticulture, there has been spectacular change in terms of adoption of new technologies, production and availability of horticulture product. India is the second largest producer of fruits in the world after China with an annual production of 47.5 million tons from an area of 4.0 million hectares and contributing $11.84 \%$ and $13.36 \%$ of the total world production of fruits and vegetables respectively (Choudhary S.K. (2013)). In India, horticultural development was not prioritized till 1990's. Principal focus of the country was on cereals in the period of 1948-80. It was in 1980-92 the consolidation of institutional support and a planned process for the development of horticulture came into existence. In post-1993 period the focused attention was given to the development of horticulture and this period is known as a "golden revolution" in horticultural production. The result of these efforts led to marginal increase in production from 7.5 tons per hectare in 1991-92 to 11.5 tons per hectare in 2013-14 (NHB, 2014).

The concept of apple cultivation was introduced into the country by the British firstly in the Kullu Valley of the Himalayan State of H.P. as far back as 1865, while the colored 'Delicious' cultivars of apple were introduced to Shimla hills of the same State in 1917. The apple cultivar 'Ambri', is considered indigenous to Kashmir and had been grown long before Western introductions. The fruit culture in Kashmir valley dates back to the times of King Nara (1000 BC), King Lalitaditya (700 AD) and Harsha (1089 AD). Over 700 cultivars of apple, introduced from USA, Russia, U.K., Canada, Germany, Israel, Netherlands, Australia, Switzerland, Italy and Denmark have been tried and tested during the last 50 years. The delicious group of cultivars predominate the apple market.

In India all deciduos fruits including pome fruits (apple and pear) and stone fruits (peach, plum, apricot and cherry) are produced in considerable quantity. The fruit growing states of India include the North-Western Indian States of Jammu and Kashmir (J\&K), Himachal Pradesh (H.P.) and in Uttaranchal and the North-Eastern Hills region, comprising of the States of Arunachal Pradesh, Nagaland, Meghalaya, Manipur and Sikkim also grow some of the deciduous fruits on a limited scale. Out of all the deciduous fruits, apple is the most important in terms of production and extent.

The horticultural sector forms the backbone of the economy of Jammu and Kashmir. The state government has declared the horticulture to be one of the most important economic sectors of the state that has contributed immensely to the strengthening of the financial condition of Jammu and Kashmir. The varied agroclimatic zones in the state, ranging from sub-tropical in Jammu, temperate in Kashmir and cold arid in Ladakh, 
make it ideal to grow diverse produce ranging from exotic fruits and vegetables to flowers, aromatic plants and medicinal herbs. The horticultural sector contributes yearly Rs.5000 crores (i.e. 7-8 percent of the GSDP) to state economy.

The horticulture sector in J\&K accounts only for 13 per cent of the net sown area but contributes 45 per cent of the state's agricultural GDP. It provides employment to around 7 lakh families comprising of about 33 lakh people who are directly or indirectly associated with this sector. Each hectare of Orchard generates employment of 400 man-days per year i.e. 13.80 crore man-days per annum.

Area under Fruits in J\&K State has increased from 3.25 lakh hectares in 2010-11 to 3.55 lakh hectares in 2013-14. The production has increased from 17.13 lakh MTs in 2009-10 to 21.17 lakh MTs in 2013-14, recording an increase of $23.58 \%$ (E. Survey, 2013-14). Moreover, the forward and backward linkages in the sector which include inputs, packing, processing and transportation have significant employment potential in the state.

To initiate the growth of horticulture sector, Govt. of India \& State Govt. have taken efficient measures such as 'Technology Mission for Integrated Development of Horticulture' and market interventions viz. establishment of fruit markets, provision for support price, technological support, awareness options, publicity inputs, research extension etc.

\section{Need for Financing the Apple industry}

Horticultural crops often require intensive input requirement and necessitate large labor inputs for harvest, and planning that cannot be met with family labour alone. This process puts the challenges for the government and financing agencies to come near the door steps of peasants involved horticultural practices and help them to avail the credit for the overall horticultural development and to meet working capital requirements during process of production season and overhead costs associated with the marketing of final produce. Which in return lead to increased employment opportunities and rising wage levels.

Apple growers financing schemes have become an important input due to the advent of capital intensive cropping technologies. Farmers require capital in order to enhance the productivities of various farm resources and marketing of produce. Indian agriculture/horticulture, in general, is characterized by low and uncertain returns. In order to break the vicious cycle of low returns, low savings, low investment, low returns, provision of external finance to farmers becomes inevitable. In order to meet various expenses as discussed below, huge amount of capital is required, which cannot be fulfilled from the one year production profits. Thus in order to meet their requirements, peasants go for different ways of raising credit.

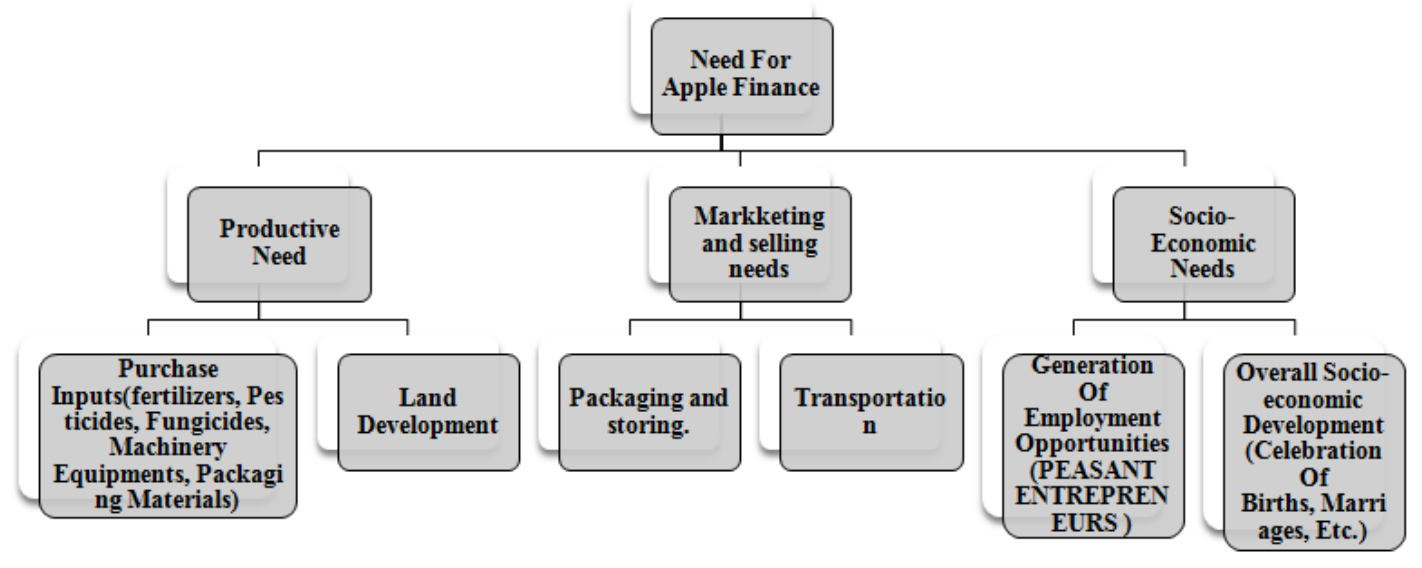

Figure 1.

A. Productive needs: Monetary obligations to meet the requirements of the effective cropping are broadly divided into the two categories.

1. Inputs Requirements:Inputs such as fixed horticultural equipments which include Spray Pumps, water pumps, tiller, grass cutters etc. require the huge investments and they demand the growers to raise the external credit facilities to carry out smooth functions.

2. Land Development:The orchard establishment cost is the sum of the costs for the land preparation/ development, plantation, plaguing, cash overhead and production expenses for growing the trees through the first 5-7 year till the apples are harvested (gestation period). Usually the cash crops cultivated during the gestation period subside the overhead costs required. But the costs associated with the fertilizers, horticulture mineral oil sprays and pesticides are considered as the financial obligation over the growers. 
B. Marketing and selling needs. These needs are categorized as.

1. Packaging and Storing: packaging the apple to sell it in the market is labour and capital intensive. The average packaging requires materials such as the box, straw, paper, tape, ink etc. which roughly comprise the $10 \%$ of the gross sales value on per box of apple produce. On the other hand the storage facilities are limited in the valley and the amount charged is varying on the basis of the time duration to keep them in the cold stores.

2. Transportation: the transportation costs to the final selling place are deducted from the gross sales proceeds, but the local transportation costs are directly throwing the burden on the growers. The local transport here we mean by the amount required to make the packaged apple boxes available on road for truck loadings. The local transportation means are small load carriers, carts, horses and mules.

\section{Socio-Economic Needs:}

Apart from the productive and marketing needs, the socio-economic needs, as will be discussed, are the financial obligations on the growers which they have to meet out of the orchard incomes. Because the orchards are the main source of income in most of the cases in the state and thus any financial obligation or contingency which arises in the family are met by the income of the orchards. These needs are broadly as.

1. Overall Socio-economic Development: The financial requirements for overall socio-economic development such as the celebration of births, marriages and construction of house etc. are met out of the farm incomes. So this also remains one of the main reasons to raise credit from the market in against the expected orchard produce.

2. Generation of Employment Opportunities (PEASANT ENTREPRENEURS): Peasant entrepreneurs as will be discussed in later sections raise the amount from the commercial banks or from the outside state fruit commission and forwarding agents to lend this money to the marginal growers on higher interest rates to generate employment for themselves. They require huge capital to intern earn from this by lending it to marginal farmers.

\section{Literature Review}

Lad (2013) has investigated the reasons regarding requirements of finance during the cultivation process. He has highlighted three categories of financing. Such as short-term (to meet domestic expenses and inputs on process of production) medium-term (land improvement) long-term financing (for purchasing agricultural machinery as well as pay off debts.

Sahaf (1984) has highlighted the importance of finance in apple industry of Jammu and Kashmir. He has emphasized on the need of finance to help producers to meet their working capital requirements and marketing related expenses. Rubin et al. (2005) studied that the increasing consumption of horticultural products is driven by rising incomes, urbanization, health awareness and changing labor practices. Urbanization and changes in the labor market, including the expanded presence of women in the workforce, amplify the demand for convenience foods (prepared salads, fresh-cut fruits, restaurant food, etc.) as well as novel and exotic horticultural products that will play a significant role in future demands of high-value products. Baht (2005) studied the working performance of cooperative Land Development Bank of J\& K state and have revealed various purposes wise loans for horticultural development such as loans for fruit garden raising, purchase of machinery equipment, redemption of prior debts, orchid development, establishment of processing houses and transportation of horticultural produce. Golait (2007) studied the evolution of institutional credit to agriculture could be broadly classified into four distinct phases - 1904-1969 (predominance of co-operatives and setting up of RBI), 1969-1975 [nationalization of commercial banks and setting up of Regional Rural Banks (RRBs)], 1975-1990 (setting up of NABARD) and from 1991 onwards (financial sector reforms).

Sidhu and Gill (2006) carried out a study on Agricultural Credit and Indebtedness in India and they pointed out three major challenges of the financial institutions for agriculture financing- 1) the flow of agricultural credit has to be increased 2) the accessibility of formal credit to rural poor and disadvantaged and agriculturally less developed regions has to be improved and 3) the economic viability of rural banking operations has to be ensured over time. They suggested that the agricultural credit should be improved further by covering a large number of farmers, who were unable to access the formal credit due to rigidity in lending procedures and requirements, rigidity in loan products and by increasing the quantum of credit flow. Cost of borrowing to the farmers was another important issue affecting the flow of credit to the agriculture sector.

Weinberger \& Lumpkin (2007) have highlighted the need of market institutions that provide farmers with timely price information and access to credit. Kumar (1987) reported that the co-operatives had an upper hand in contrast to commercial banks. He observed that the adoption of new technology and increase in the average high yield was the conclusive proof that agricultural financing by banks had helped the farmers to a great extent. It was revealed that the process of getting loans was a difficult task and that frequent visits to banks and expenditure associated with it had compelled some of the farmers not to apply. 
Srivastava (1987) made an analytical study on Institutional Financing of Agriculture in India. He concluded that more than half of the loans and advances provided to farmers had come from co-operative credit institutions and the share of commercial banks in the total loans and advances had declined during the period of study. The study also showed that the commercial banks had enormous amounts of overdue, because of the diversion of loans from productive purposes to unproductive purposes, lack of supervision by the lending authorities and political interferences.

Ramakrishna (1989) in his book, Agricultural Households and Institutional Finance, cited that the institutional finance had not fully relieved the farmers of the abusive holds of the moneylenders. He concluded that more credit should be pumped into the rural sector for both productive and consumption purposes to meet all the financial needs of the farmers. Reddy (1991) examined the Role of Institutional Finance in Indian Agriculture and concluded that the farm business income was more or less equal between borrowers and nonborrowers, which means institutional credit had no significant effect on farm income. He also remarked that there was considerable difference in the distribution of farm credit per household. Mohideen (1991) made an attempt in his study Institutional Credit and Agriculture Development to assess the supply of credit, the extent of overdue and its causes, impact of institutional credit on repayment capacity and productivity gains. He reported that institutional credit was essential for farm production and that it had helped the farmers to use the credit more effectively. As the existing credit supply was insufficient to meet the agricultural needs of farmers, the credit should be given for all purposes including consumption purpose for loans. He also argued for better coordination among the different institution to get better results and suggested the mobilization of deposits from rural areas, improvement in the overall efficiency of co-operatives and effective linking of credit with marketing and better supervision of the end use of loans.

Sharma (2007) has highlighted the declining trends of financing in agriculture through public sector. At national level a large number of formal and informal institutional agencies such as Co-operatives, Regional Rural Banks (RRBs), Scheduled Commercial Banks (SCBs), Self-help Groups (SHGs) are involved in meeting the short- and long-term needs of the farmers (Kumar et al., 2010). Das et al. (2009) studied that the credit facilities act as the driving forces for the growth in agriculture production and observed the shortcomings in the present credit delivery system. Usually the small and marginal holders face the problems in the prevailing credit delivery system and the final produce is directly linked with the availability of finance in the priority sector.

\section{Comparative Analysis}

The comparative analyses between institutional and non-institutional sources of finance have support as well as criticize both the sources of finance on some strong grounds. The institutional sources are considered as the opportunistic as they offer the credit on the pre-specified terms and they usually operate at moderate levels of interest rates. While as the non- institutional sources have many hidden costs associated and usually higher interest rates. On the other hand the availability of the institutional financing sources is less than the noninstitutional sources because the major players of the non-institutional financing sources are the money lenders who are readily available to provide the credit at the door steps of the peasants.

The utilization of the financing facilities from the various players in the horticulture sector operational in the country is showing declining trend in the non-institutional sources and inclined trend in the institutional financing sources. These changes can be attributed to the measures taken by the planning commission of central government to uplift the rural and agricultural infrastructure. Various schemes from the central bank and extensive support from the government of India have made the institutional financing more easily available and accessible. Recognizing the importance of agriculture sector in India's development, the Government and the RBI have played a vital role in creating a broad based institutional framework for catering to the increasing credit requirements of the sector. Credit, the non-land input, has two dimensions from the viewpoint of its contribution to amplification of agricultural growth, namely, availability of credit and distribution of credit. In India a multi agency approach comprising Co-operatives Banks, Scheduled Commercial Banks and Regional Rural Banks has been followed for purveying credit to agriculture sector. The policy of agricultural credit is guided mainly by the considerations of ensuring adequate and timely availability of credit at reasonable rates through the expansion of institutional framework, its outreach and scale as also by way of directed lending. Two innovations, namely, micro credit and Kissan Credit Card (KCC) scheme have emerged as a major policy development in addressing the infirmities connected with the distributional aspects of credit in the recent years. The KCC has emerged as the most effective mode of credit delivery to agriculture in terms of the timeliness, hassle-free operations, as also adequacy of credit with minimum of transaction costs and documentation. The flow of investment credit to agriculture is constrained by a host of factors such as high transaction cost, structural deficiencies in the rural credit delivery system, issues relating to credit worthiness, lack of collateral security in view of low asset base of farmers, low volume of loans with associated higher risks, high man power requirements, etc. The growing disparities between marginal, small and large farmers continue to be a cause for concern. This pragmatic phenomenon might attribute, inter alia to the risk aversion propensity of the bankers towards small and marginal farmers as against the large farmers who are better placed in offering collaterals. 
Financing the Apple Industry of Jammu and Kashmir: A Review of Literature

Table-1: Relative Share of Borrowings of Cultivator Households across India from Different Sources

\begin{tabular}{|l|l|l|l|l|l|l|l|}
\hline \multirow{2}{*}{ Sources } & \multicolumn{9}{|l|}{ Year } & $\mathbf{1 9 6 1}$ & $\mathbf{1 9 7 1}$ & $\mathbf{1 9 8 1}$ & $\mathbf{1 9 9 1}$ & $\mathbf{2 0 0 2}$ & $\mathbf{2 0 1 0}$ \\
\cline { 2 - 9 } & $\mathbf{1 9 5 1}$ & $\mathbf{1 9 6 1}$ & $\mathbf{6 8 . 3}$ & $\mathbf{3 6 . 8}$ & $\mathbf{3 0 . 6}$ & $\mathbf{3 8 . 9}$ & $\mathbf{2 9 . 7}$ \\
\hline Non_institutional of which & $\mathbf{9 2 . 7}$ & $\mathbf{9 1 . 3}$ & $\mathbf{6 8 . 3}$ & 21.9 \\
\hline Money lender & 69.7 & 49.2 & 36.1 & 16.1 & 17.5 & 26.8 & $\mathbf{6 8 . 8}$ \\
\hline Institutional of which & $\mathbf{7 . 3}$ & $\mathbf{1 8 . 7}$ & $\mathbf{3 1 . 7}$ & $\mathbf{6 3 . 2}$ & $\mathbf{6 6 . 3}$ & $\mathbf{6 1 . 3}$ & $\mathbf{6}$ \\
\hline Cooperative societies/banks & 3.3 & 2.6 & 22.0 & 29.8 & 23.6 & 30.2 & 24.9 \\
\hline Commercial Banks & 0.9 & 0.6 & 2.4 & 28.8 & 35.2 & 26.3 & 25.1 \\
\hline Unspecified & - & - & - & - & $\mathbf{3 . 1}$ & - & $\mathbf{1 . 5}$ \\
\hline Total & $\mathbf{1 0 0 . 0}$ & $\mathbf{1 0 0 . 0}$ & $\mathbf{1 0 0 . 0}$ & $\mathbf{1 0 0 . 0}$ & $\mathbf{1 0 0 . 0}$ & $\mathbf{1 0 0 . 0}$ & $\mathbf{1 0 0 . 0}$ \\
\hline
\end{tabular}

Source: All India Debt and Investment Survey and NSSO.

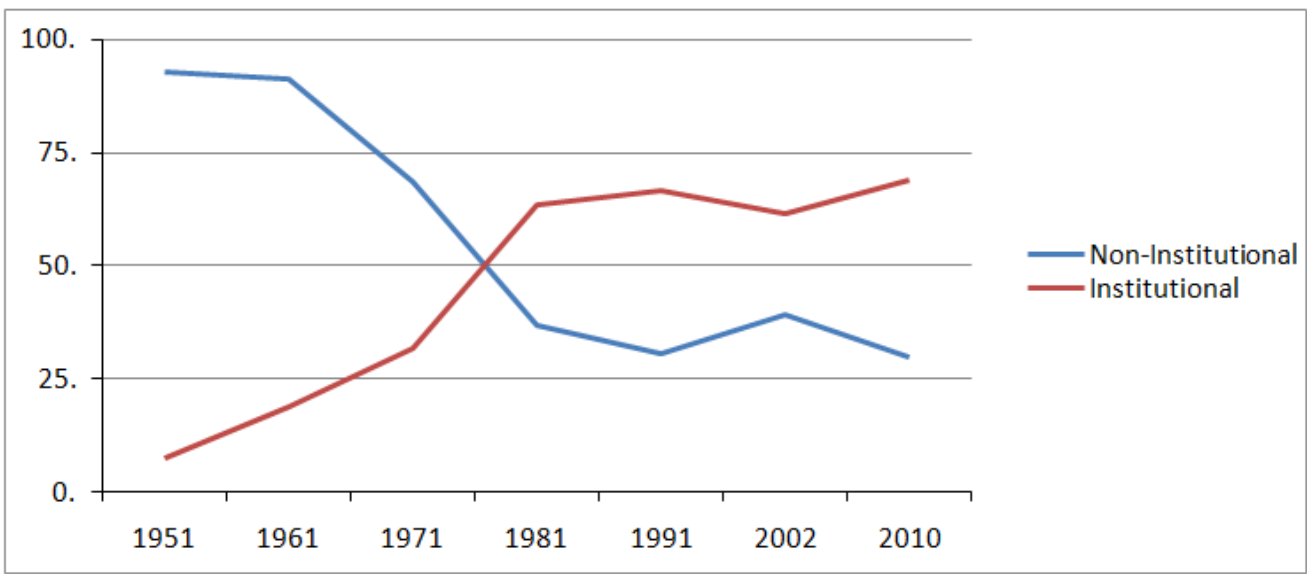

Figure 2: Showing the trend in the usage of financial intermediary over period of time.

\section{Conclusion}

The primary and traditional sources are mostly non-institutional.The small and marginal peasants of the state barrow money against the expected produce from local money lenders (peasant entrepreneurs) ${ }^{1}$. Among the non-institutional financing sources, the local peasant entrepreneurs and outside state fruit merchants play the major role. These sources provide credit facilities to peasants annually at higher rates of interests. The underlying credit raising processes are easy but impose higher financial risk.

The peasant entrepreneurs of the state use to lend money at an basic interest of ₹30 per box of apple and a general agreement is made between peasant and entrepreneur to purchase all viable inputs from the entrepreneur and for marketing of produce peasant remains dependent on entrepreneur. The process in turn enhances entrepreneur to earn commission from viable inputs and commission returns from fruit market which leads to the cumulative interest near about $₹ 100$ per box of apple $(20 \% \text { Interest rate })^{2}$.

The supplementary source of non-institutional finance is from different fruit markets established throughout the country. The fruit commission agents use to lend money to peasants in the moths of March-April ${ }^{3}$ at an interest rate of $12 \%{ }^{4}$. The prevailing sources are risk prone, at the time of harvesting if the production decreases the same contract continues for the next cropping season.

While as in the recent years under the initiative of government of India, RBI and NABARD, the directives are issued for providing financial opportunities to the peasants at the door step. In response to it the introduction of $\mathrm{KCC}^{5}$ and Apple Growers Advance schemes, peasants have started to replace non-institutional financing with institutional financing sources. The study revealed that the peasants having holding size above 1 hectare use to go for institutional financing. The institutional financing sources especially commercial banks ${ }^{6}$

\footnotetext{
${ }^{1}$ Peasant entrepreneur are known as Aaret or Bapeer in Kashmiri language. They have usually large holding size and they barrow money from outside state markets and from banks and lend that money to small peasants at higher rates of interests.

${ }^{2}$ On an average one box of apple costs around 500 .

${ }^{3}$ Flowering season of fruits.

${ }^{4}$ Commission charged of gross sale of per box of apple,

${ }^{5}$ Kisan Credit Card

${ }^{6} \mathrm{Jammu}$ and Kashmir bank remains at the priority.
} 
lend money under KCC scheme against holding size ${ }^{7}$, which is ₹30,000 to 50,000 per $\mathrm{Kanal}^{8}$ of land. Under this scheme peasants have to pay an annual interest rate of $7 \%{ }^{9}$ below ₹3 Lakhs and if the amount exceeds this limit, the interest rate increases to $12 \%$.

On the other hand apple growers advance scheme is another available institutional financing source provided by commercial banks. The peasants requiring higher amounts opt for this in comparison to KCC the interest rates vary @ $14 \%$ annually.

\section{References}

[1]. Ahangar, G. B., Ganie, A., \&Padder, M. (2013).A study on institutional Credit to agriculture sector in India. International Journal of Current Research and Academic Review, Vol.1(4).

[2]. B.C. Apple Industry Analysis, (2012). Strategic Choice and Directions for Net Decade, by Globalwise Inc., Vancouver, WA

[3]. Bhat N. \& Ahmad R. (2005). Business Performance Of Central Cooperative Land Development Bank Of J \& K State. Banking: Trends and Practices. 227.

[4]. Choudhary S.K. (2013). CONTRIBUTION OF NATIONAL HORTICULTURE MISSION IN AGRICULTURAL DEVELOPMENT. International Journal of Advanced Research in Management and Social Sciences, 2(6), 52-64.

[5]. Das A. Senapati M. \& John J. (2009). Impact of Agricultural Credit on Agriculture Production: An Empirical Analysis in India. Reserve Bank of India Occasional Papers. Vol.30(2).

[6]. Golait R. (2007). Current issues in agriculture credit in India: An assessment. Reserve Bank of India Occasional Papers. 28(1). pp 89-99.

[7]. Kumar K. (1987). Institutional Financing of Indian Agriculture with Special Reference to Commercial Banks. Deep and Deep Publications. New Delhi.

[8]. Kumara, A., Singh, K., \&Sinha, S. (2010). Institutional Credit to Agriculture Sector in India: Status, Performance and Determinants. Agricultural Economics Research Review, Vol. 23, Pp 253-264.

[9]. Lad B. (2013). Agriculture Finance: An Overview. Research Directions. Vol. 1(1)

[10]. Lad, B. (2013). Agriculture Finance: An Overview. Research Directions. Vol 1(1).

[11]. Rubin D. Cummings R. \& R. Harwood. (2005). Agriculture and Natural Resources Management Research Priorities Desktop Review.1 st draft. USAID, Washington D.C.

[12]. Sahaf M. A. (1985). Marketing of Horticulture Produce in Jammu and Kashmir State - A Case Study of Apple Industry. Ph.D Thesis. University of Kashmir.

[13]. Sharma V. (2007)." India's Agrarian Crisis and Smallholder Producers' Participation in New Farm Supply Chain Initiatives: A Case Study of Contract Farming". Indian Institute Of Management Ahmedabad, India. W.P. No.2007-08-01.

[14]. Sharma, V. (2007). India's Agrarian Crisis and Smallholder Producers' Participation in New Farm Supply Chain Initiatives: A Case Study of Contract Farming. INDIAN INSTITUTE OF MANAGEMENT AHMEDABAD, INDIA, W.P. No.2007-08-01.

[15]. Sheikh, S., \&Tripathi, A. (2013). ). Socioeconomic conditions of Apple growers of Kashmir Valley: A case study of district Anantnag. International Journal of Educational Research and Technology., Vol.4(1).

[16]. Srivastava R.B. (1987). Institutional Financing of Agriculture in India. Vohra Publishers and Distributors. Allahabad.

[17]. Suryawanshi, S. (2011).Sources of Agricultural Finance: A Role of Cooperative. International Referred Research Journal, Vol. III(31), 44-46.

[18]. Weinberger K. \& Lumpkin T. A. (2007). Diversification into horticulture and poverty reduction: a research agenda. World Development. 35(8). 1464-1480.

\footnotetext{
${ }^{7}$ Mortgaged land (Legal Contract is signed between bank and peasant).

${ }^{8} 8$ Kanals of land is equal to one Acre of land.

${ }^{9} 4 \%$ interest is payable by peasant and remaining $3 \%$ is being subsidized by GOI
} 